Available online at GSC Online Press Directory

GSC Biological and Pharmaceutical Sciences

e-ISSN: 2581-3250, CODEN (USA): GBPSC2

Journal homepage: https://www.gsconlinepress.com/journals/gscbps

(RESEARCH ARTICLE)

\title{
Evaluation of the in-vivo antitrypanosomal activity of the crude extract of Moringa oleifera (lam) against rats infected with Trypanosoma brucei
}

Datti Yau 1, ${ }^{*}$, Musa Ibrahim ${ }^{1}$, Ali Usman Lado ${ }^{1}$, Mustapha Abdulhadi ${ }^{1}$, Tijjani Yahya Ahmad ${ }^{1}$, Koki Isa Baba

1, Ado Abubakar Sulaiman 1, Musa Shuaibu Muhammad ${ }^{1}$ Adamu Garba Alhaji ${ }^{2}$ and Umar Aliyu 2.

${ }^{1}$ Department of Chemistry, Yusuf Maitama Sule University, Kano, Nigeria.

${ }^{2}$ Department of Science Laboratory Technology, Kano Sate Polytechnic, Nigeria.

Publication history: Received on 17 March 2020; revised on 31 March 2020; accepted on 01 April 2020

Article DOI: https://doi.org/10.30574/gscbps.2020.11.1.0068

\begin{abstract}
The anti-typanosomal effect of the crude extract of the leaves of Moringa oleifera was determined in-vivo in Trypanosoma brucei-infected rats. In the study, twenty five rats (weighing between 255-261 g) were grouped into five (A, B, C, D and E), with their parasitaemia levels and packed cell volumes (PCV) all determined before the analysis. Each rat was then injected with blood sample infected with the Trypanosoma brucei parasite. The infected rats were allowed to stay untreated for six days, during which the parasitaemia level for each of the rats was determined at two days intervals. The crude extract of the leaves of Moringa aleifera $(200 \mathrm{mg} / \mathrm{Kg}$ ) was orally administered ad libitum six days post-infection to rats in the first four groups (A, B, C and D), while the last group (E) was orally given distilled water (free from the extract). The effect of the extract on trypanosome-infected and treated rats was monitored for 6 days (at 2 days intervals). This was done by determining the changes in the parasitaemia levels and the packed cell volumes (PCV) of the blood of the rats. The results showed a significant decrease in the parasitaemia levels after treatment with the extract, with significant gain in the PCV of the treated rats. However, results from the untreated group (E) was not encouraging, as three of the untreated rats died before the end of the study.
\end{abstract}

Keywords: Trypanosoma brucei, Moringa oleifera, parasitaemia, packed cell volume.

\section{Introduction}

The African animal trypanosomiasis (AAT) found mainly in sub-Saharan Africa, is a parasitic disease that causes lots of economic losses in animals ranging, from anaemia to emaciation, with many of such cases if untreated being fatal. AAT is found mainly in the regions of Africa where the biological vector of AAT, tsetse fly, exists (CFSPH, 2009). Among the major animal diseases, bovine trypanosomiasis proves to be the major constraints of livestock production in SubSaharan Africa. The social, economic and agricultural development of communities within tsetsefly infested areas are greatly affected by the risk of infection in both humans and in domestic animals, with such communities roughly constituting more than a third of Africa (FAO, 2002; Radostits et al., 2007).

The African animal trypanosomosis is one of the major obstacles encountered in livestock production in sub-Saharan Africa, causing reduction in milk production, as well as causing great weight loss and hindering reproduction within the animals, and eventually, in almost all cases, death of the affected animals (Hoet et al., 2004). The disease has been reported to cause the death of about 3 million cattle a year while 50-70 million animals are exposed to the infection (Ogbadoyi et al., 2007). It is also reported that the disease is present in over 37 countries, causing an annual economic loss of over 4.75 billion US dollars (DFID, 2001). Human African trypanosomosis affects more than 60 million people

\footnotetext{
* Corresponding author: Datti Yau
} 
worldwide with 300,000-500,000 new cases of both East and West African trypanosomosis reported each year (Kubata et al., 2005; WHO, 2004).

There is a slim and poor chance of developing vaccines for trypanosomes, because the parasites have a glycoprotein coat encoded by genes that are antigenically distinct, and this makes the parasite able to engage an immune-evasive process of antigenic variation (Borst and Fairlamb, 1998). Thus, drugs are the only viable management options for tackling this problem. However, all the currently available drugs have serious limitations, which include high cost, serious side effects, long-course of parenteral administration, variable efficacy and emergence of drug resistant trypanosome strains (Gutteridge, 1984; Croft, 1997; McDermont et al., 2002; Brun et al., 2001; Maikai, et al., 2008). The presence of drug resistant trypanosomes has recently risen to alarming proportions (Legros et al., 1999; Brun et al., 2001; Stanghellini and Josenando 2001; Maikai, et al., 2008). Treatment of the late stage of sleeping sickness with Melarsoprol (Mel B), a trivalent arsenical, is hazardous, causing reactive encephalopathy in $5-10 \%$ of patients treated, with $1-5 \%$ mortality (Kennedy, 2004). The problem of drug resistance has been aggravated by lack of new drug development initiatives by major pharmaceutical firms. There is therefore, an urgent need to develop new effective and safe chemotherapeutic agents for the treatment of the African Trypanosomiasis.

In many countries where African trypanosomiasis occur, different plants have been used traditionally for centuries and are still widely used to treat this illness. It is estimated that two-third of the world population rely on traditional medical remedies due to the limited availability and affordability of pharmaceutical products (Tagboto and Townson, 2001). Some common plants known to be traditionally used in the treatment of the African Trypanosomiasis include Adansonia digitata (Ibrahim et al., 2013), Lawsonia inermis and Ficus syncomorus (Atawodi et al., 2003) Acacia nicotida (Ahmad et al., 2008; Ogbadoyi et al., 2011a), Senna occidentalis (Mahmout et al., 2008), Ocimum gratissimum (Mpiana et al., 2007), Strychnos spinosa (Lockett and Grivetti, 2000), Vitex doniana (Mann and Ogbadoyi 2012) and Zingeber officinale (Shaba et al., 2011), Moringa oleifera (Edoga et al., 2013).

In this study, the effect of oral administration of the crude extract of Moringa oleifera on the parasitaemia level and PCV of rats infected with trypanosoma brucei was investigated.

\section{Material and methods}

\subsection{Plant Materials}

The leaves of Moringa oleifera were collected from the Na'ibawa Qtrs. in Tarauni Local Government, in Kano state, Nigeria, and the plant was identified by a plant taxonomist from the Department of Biological Sciences, Yusuf Maitama Sule University, Kano, with a voucher number YUHAN 0021 assigned to it, and a voucher specimen deposited at the herbarium of the department.

\subsection{Sample Preparation}

The leaves were dried at room temperature $\left(35\right.$ to $\left.37^{\circ} \mathrm{C}\right)$ to a constant weight. The dried leaves were grounded to fine powder and then stored in a dry container.

\subsection{Solvent Extraction of the Plant Samples}

Hundred grams ( $100 \mathrm{~g}$ ) of the powdered sample was soaked in $400 \mathrm{ml}$ of absolute ethanol for forty eight hours (48 hrs) and stored away from direct light. The supernatant was decanted and filtered using filter paper. The filtrate was evaporated to dryness, and stored in sample bottles at room temperature to avoid biological degradation.

\subsection{Experimental Animals}

Twenty five rats weighing between 255 and $261 \mathrm{~g}$ obtained from the Laboratory animal unit of Department of Physiology, Bayero University, Kano were used for the study. The rats were housed in clean cages in fly-proof house at room temperature and fed with commercial feed (Vital feeds, GCOM Nig. Ltd) and provided with clean water ad libitum. The rats were screened for the presence of blood parasites using wet and Giemsa-stained thin films prior to commencement of the experiment. The packed-cell-volume (PCV) of the rats was also determined prior to the commencement of the trypanosomal infection. The PCV ranged between 40 to $42 \%$, signifying that they are all within the normal PCV range for rats (39-46\%) as reported by Qili et al., (2017). 


\subsection{Trypanosomes and Infection}

The Trypanosoma brucei isolate was obtained from The Nigerian Institute for Trypanosomiasis Research (NITR). The parasites were propagated and maintained in rats few days before the commencement of the research. Twenty five (25) rats were used for the research, and they were grouped into five, with each group comprising of five rats. During the trypanosomal infection group A was inoculated with $0.2 \mathrm{ml}$ of the blood sample infected with typanosoma brucei. Same was done for groups B, C, D and E.

\subsection{Parasitaemia, Blood Sampling, Determination of Packed-Cell Volume and Treatment}

The parasitaemia level for each rat in every group was determined at two days interval. To estimate the number of circulating parasites in each infected rat, the rapid 'matching' method by Herbert and Lumsden (1976) was adopted, where parasite were seen by direct microscopy. At two days interval, blood was taken from each rat by tail snip into $100 \mu \mathrm{l}$ microhaematocrit tubes for PCV determination in accordance with a method by Woo (1970). The average for each group was then calculated for each sampling point.

All experimental rats from groups A, B, C, D and E, showed detectable parasitaemia around day 6 post infection. Hence, treatments commenced at about day 6 post infection (taken as Day 0) at the first detection of parasitaemia. Crude Moringa oleifera extract was given at a dose of $200 \mathrm{mg} / \mathrm{Kg}$ orally for 6 consecutive days to rats from groups A, B, C and $\mathrm{D}$, while rats from group $\mathrm{E}$ served as the control experiment. The infected but non-treated control group received distilled water orally for 6 days.

\section{Results and discussion}

The results for the average parasitaemia levels after inoculation and treatment are presented in Tables 1.0 and 2.0 respectively; while the PCV of the rats after infection are presented in Table 3.0.

Table 1 Average parasitaemia level after inoculation

\begin{tabular}{llllll}
\hline Day & Group A & Group B & Group C & Group D & Group E \\
\hline 0 & $0 \%$ & $0 \%$ & $0 \%$ & $0 \%$ & $0 \%$ \\
2 & $0.1 \%$ & $0.2 \%$ & $0.2 \%$ & $0.2 \%$ & $0.1 \%$ \\
4 & $0.8 \%$ & $0.7 \%$ & $0.7 \%$ & $0.8 \%$ & $0.8 \%$ \\
6 & $1.4 \%$ & $1.4 \%$ & $1.3 \%$ & $1.4 \%$ & $1.3 \%$ \\
\hline
\end{tabular}

Table 2 Average parasitaemia level after treatment

\begin{tabular}{cccccc}
\hline Day & Group A & Group B & Group C & Group D & Group E \\
\hline 0 & $1.4 \%$ & $1.4 \%$ & $1.3 \%$ & $1.4 \%$ & $1.3 \%$ \\
2 & $0.5 \%$ & $0.4 \%$ & $0.4 \%$ & $0.5 \%$ & $1.8 \%$ \\
4 & $0.1 \%$ & $0.09 \%$ & $0.08 \%$ & $0.1 \%$ & $2.5 \%$ \\
6 & $0.05 \%$ & $0.04 \%$ & $0.03 \%$ & $0.05 \%$ & $3.0 \%$ \\
\hline
\end{tabular}

Table 3 The PCV of the rats after infection

\begin{tabular}{llllll}
\hline S/N & Group A & Group B & Group C & Group D & Group E \\
\hline 1 & $24 \%$ & $20 \%$ & $25 \%$ & $25 \%$ & $22 \%$ \\
2 & $25 \%$ & $23 \%$ & $25 \%$ & $26 \%$ & $24 \%$ \\
3 & $24 \%$ & $26 \%$ & $24 \%$ & $25 \%$ & $24 \%$ \\
4 & $25 \%$ & $23 \%$ & $25 \%$ & $25 \%$ & $25 \%$ \\
5 & $25 \%$ & $21 \%$ & $24 \%$ & $24 \%$ & $26 \%$ \\
\hline
\end{tabular}


Three of the five rats in the control group were dead by the 10th day of the experimental treatment, and this is a clear indication that the Trypanosoma brucei strain used was highly pathogenic to rats. The in-vivo antitrypanosomal activity exhibited by the crude extract of Moringa oleifera against the Trypanosoma brucei strain supports the reports from Sunday and Hassana 2010; and Ukachi et al., 2015 who worked on some other trypanosomal species. But even though the activity of the crude extract of Moringa oleifera against the Trypanosoma brucei has been confirmed, there is still the need to extract, isolate and elucidate the structure of the compound responsible for such activity.

Treatment of the infected rats with the crude extract of the plant has shown extended survival of the rats in the treatment groups compared with the non-treated control group. This result agrees with previous reports by Abubakar et al., (2005) and Abu and Uchendu (2011) who have applied extracts of Momordica balsamina and Hymenocardia acida on T. brucei.

It is also clear from the findings of this research that the crude extract of Moringa oleifera used against the Trypanosoma brucei parasite was not able to completely eliminate parasites from the blood stream of infected rat, rather it was only able to reduce the level of parasitaemia. This agrees with researches reported by Shuaibu et al., (2008); Ogbadoyi et al., (2011b) and Ibrahim et al., (2012) that had similar observations regarding the reduction in parasitaemia, and the conclusion to that might be that presence of the high load of the parasite has masked and overshadowed the efficacy of the extract used, and this conclusion is fully in agreement with that of Ekanem et al., (2008) and Abu and Uchendu (2011). Moreso, the crudeness of the extract, the route of administration and the dose might be other factors that can reduce the efficacy of the extract, and conclusion agrees with that from Tsegabirhan et al., (2014).

The drastic reduction and fall in the packed-cell-volume (PCV) of the trypanosome-infected rats is a reliable indication of the disease status, as the measurement or degree of anaemia in the infected rats can be said to be directly proportional to the level of paracetaemia in the rats' blood. Reports by Ekanem et al., (2008) and Saleh et al., (2009) also associates high decline in PCV (acute anaemia) in trypanosomal infection to the increase in the number of the parasites. The result of this study showed that the crude extract was able to control the increase in anaemia, especially at the later stages of the infection, by minimizing drops in PCV values. In the untreated rats, the parasite count increased and the packed cell volume (PCV) decreased markedly until some of the animal died, as was also observed in previous studies by Ekanem et al., (2008) and Saleh et al., (2009).

\section{Compliance with ethical standards}

\section{Acknowledgments}

Our acknowledgment goes to the management of Yusuf Maitama Sule University, Kano who gave full financial, moral and technical support to this research.

\section{Disclosure of conflict of interest}

Some of the materials required for the research had to be obtained from a sister University, and this has not been as easy as it sounds, because it contradicts the policy of our University.

\section{Statement of ethical approval}

The present research work obtained approval from the National Health Research Ethics Committee of Nigeria as the research contains some studies performed on animals (rats).

\section{References}

[1] Abu AH and Uchendu CN. (2011). In-Vivo Trypanocidal Activity of Hydroethanolic Extract of Hymenocardia acida Stem Bark in Rats. Vet World, 4, 113-116.

[2] Abubakar A, Iliyasu B, Yusuf AB, Igweh AC and Onyekwelu NA. (2005). Antitrypanosomal and Haematological Effects of Selected Nigerian Medicinal Plants in Wistar Rats. Biokemistri, 17, 95-99.

[3] Ahmad M, Zaman F, Sharif T and Zabta CM. (2008). Antidiabetic and Hypolipidemic Effects of Aqueous Methanolic Extract of Acasia nilotica Pods in Alloxan-Induced Diabetic Rabbits. Scand. J. Lab. Anim. Sci, 35, $29-34$.

[4] Atawodi SE, Bulus T, Ibrahim S, Ameh DA, Nok AJ, Mamman M and Galadima M. (2003). In-Vitro Trypanocidal Effect of Methanolic Extract of Some Nigerian Savannah Plants. Afr. J. Biotechnol, 2, 317-321. 
[5] Borst P and Fairlamb AH. (1998). Surface Receptors and Transporters of Trypanosoma brucei. Ann Rev Microb, 52, 745-778.

[6] Brun R, Schumaker R and Schmid C. (2001). The Phenomenon of Treatment Failures in Human African Trypanosomiasis. Trop Med Intern Health, 6, 906-914.

[7] CFSPH. (2009). African Animal Trypanosomiasis. The Center for Food Security and Public Health (CFSPH), Iowa State University. www.cfsph.iastate.edu.

[8] Croft SL. (1997) .The Current Status of Anti-Parasitic Chemotherapy. Parasit, 114, 53-55.

[9] Department For International Developemnt, DFID. (2001). Trypanosomosis, Tsetse and Africa. The Year 2001 Report, 15.

[10] Edoga CO, Njoku 00, Amadi EN and Afomezie PI. (2013). Effect of Aqueous Extract of Moringa oleifera on Serum Protein of Trypanosoma brucei-Infected Rats. Int. J. Sci. Technol, 3, 85-87.

[11] Ekanem JT, Kolawol OM and Abbah OC. (2008). Trypanocidal Potential of Methanolic Extracts of Bridelia ferruginea Benth in Rattus novergicus. Af J Biochem Res, 2, 45-50.

[12] Food and Agriculture Organization (FAO). (2002). Program Against African Trypanosomiasis (PAAT). Twenty second Regional Conference for Africa, Cairo, Egypt, 4-8.

[13] Gutteridge WE. (1984). Existing Chemotherapy and its Limitations. Brit Med Bull, 41, 162-168.

[14] Herbert WJ and Lumsden WH. (1976). Trypanosoma brucei: Rapid 'Matching' Method for Estimating the Host's Parasitemia. Exp Parasit, 40, 427-431.

[15] Hoet S, Opperdoes F, Brun R., Adjakidje V and Quentin-Leclercq J. (2004). In Vitro Antitrypanosomal Activity of Ethnopharmacologically Selected Beninese Plants. Journal of Ethnopharmacology, 91, 37-42.

[16] Ibrahim H, Ogbadoyi E, Adamu K, Bello M and Yemisi I. (2012). Evaluation of Antitrypanosomal Activity of Ethyl Acetate Extract of Adansonia digitata Seed Extract in T. b. brucei Infected Albino Mice. Int J Drug Res Tech, 2, 454460 .

[17] Ibrahim HM, Ogbadoyib EO, Bellob MU and Yemisi I. (2013). Evaluation of Antitrypanosomal Activity of Adansonia digitata (Methanol Seed Extract) in Albino Mice. J. Sci. J. Vet. Adv, 2, 1-6.

[18] Kennedy PG. (2004). Human African Trypanosomiasis of the CNS; Current Issues and Challenges. J Clin Invest, 113, 496-504.

[19] Kubata BK, Nagamune K, Murakami N, Merkel P, Kabututu Z, Martin SK, Kalulu TM, Mustakuk H, Yoshida M, Ohnishi-Kameyama M, Kinoshita T, Duszenko M and Urade Y. (2005) Kola acuminata Proanthocyanidins: A Class of Antitrypanosomal Compounds Effective Against Trypanosoma brucei. International Journal for Parasitology, 35, 91-103.

[20] Legros D, Evans S and Maiso S. (1999). Risk Factors for Treatment Failure after Melarsoprol for Trypanosoma brucei gambiense Trypanosomiasis in Uganda. Trop Med Parasit, 93, 439-442.

[21] Lockett CT and Grivetti LE. (2000). Food Related Behaviour During Drought: A Study of Rural Fulani, North Eastern Nigeria. Int. J. Food Sci. Nutr, 51, 91-107.

[22] Mahmout Y, Mianpeurem T, Dolmazon R, Bouchu D and Fenet B. (2008). Amphiphile Triterpenoids from Hymenorcardia acida Tul. Phytoantimalarial and Anti-Inflammatory Activities. In Proceedings of 15 ème colloque sur la pharmacopée et la Médecine Traditionnelles Africaines, Libreville, Gabon, 1-4.

[23] Maikai VA, Nok JA and Adaudi AO. (2008). In Vitro Anti-Trypanosomal Activity of Aqueous and Methanolic Crude Extracts of Stem Bark of Ximenia americana on Trypanosoma congolense. J Med Plants Res, 2, 55-58.

[24] Mann A and Ogbadoyi EO. (2012). Evaluation of Medicinal Plants from Nupeland for Their in Vivo Antitrypanosomal Activity. Am. J. Biochem, 2, 1-6.

[25] McDermott JJ, Sidibe I and Bauer B. (2002). Field Studies on the Development and Impact of Drug Resistant Animal Trypanosomes in Market-Oriented Production Systems in the Southern Guinea Zone of West Africa. Newsletter, 2, 16-18.

[26] Mpiana PT, Tshibanga DST, Shetonde OM and Ngobula KN. (2007). In Vitro Antidrepanocytary Activity (Antisickle Cell Anaemia) of some Congolese Plants. Phytomedicine, 14, 192-195. 
[27] Ogbadoyi EO, Abdulganiy AO, Adama TZ and Okogun JI. (2007). In Vivo Trypanocidal Activity of Annona senegalensis Pers. Leaf Extract Against Trypanosoma brucei brucei. Journal of Ethnopharmacology, 112, 85-89.

[28] Ogbadoyi EO, Garba MH, Kabiru AY, Mann A and Okogun J. (2011). Therapeutic Evaluation of Acacia nilotica (Linn) Stem Bark Extract in Experimental African trypanosomiasis. Int. J. Appl. Res. Nat. Prod, 4, 11-18.

[29] Ogbadoyi E, Adamu Y and Omotosho R. (2011). Preliminary Studies of the Antitrypanosomal Activity of Garcinia kola Nut Extract in Mice Infected with T. b.brucei. Journal of Medicine and Medical Sciences, 2, 628-631.

[30] Qili H, Guoming S, Keliang L, Fangcheng Z, Yong J, Jun G, Lida L, Zhongren J, Minwu J and Huiping X. (2017) .Sexspecific reference intervals of hematologic and biochemical analytes in Sprague-Dawley rats using the nonparametric rank percentile method Plos One, 1-18.

[31] Radostits OM, Gay CC, Hinchcliff KW and Constable PD. (2007). Veterinary Medicine: A Text Book of the Diseases of Cattle, Sheep, Goats, Pigs and Horses, 10th Edn. London: Bailliere Tindall, 1608-1609.

[32] Saleh MA, Bassam MA and Sanousi SA. (2009). Oxidative Stress in Blood of Camels (Camelus dromedaries) Naturally Infected with Trypanosoma evansi. Vet. Parasitol, 162, 192-199.

[33] Shaba P, Pandey NN, Sharma OP, Rao JR and Singh RK. (2011). In Vitro Trypanocidal Activity of Methanolic Extracts of Quercus borealis Leaves and Zingiber officinale Roots Against Trypanosoma evansi. Greener J. Agric. Sci, 1, 41-47.

[34] Shuaibu MN, Wuyep PT, Yanagi T, Hirayama K and Ichinose A. (2008). Trypanocidal Activity of Extracts and Compounds from the Stem Bark of Anogeissus leiocarpus and Terminalia avicennoides. Parasitol Res, 102, 697703.

[35] Stanghellini A and Josenando T. (2001). The Situation of Sleeping Sickness in Angola: A Calamity. Trop Med Intern Health, 6, 330-334.

[36] Sunday EA and Hassana S. (2010). Antitrypanosomal Property of Some Extracts of Different Parts of Moringa oleifera, Lam. Electronic Journal of Biology, 6(1), 19-23.

[37] Tagboto S and Townson S. (2001). Antiparasitic Properties of Medicinal Plants and other Naturally Occurring Products. Adv. Parasitol, 50, 199- 295.

[38] Tsegabirhan K, Getachew T, Yacob HT, Mirutse G and Nigatu K. (2014). Effect of Crude Extracts of Moringa stenopetala and Artemisia absinthium on Parasitaemia of Mice Infected with Trypanosoma congolense. Biomed Central Research Notes, 7, 390.

[39] Ukachi EI, John OI, Samuel 00, Agunna EE, Cynthia E0, Atu AA., Gloria NE and Alexander IG. (2015). Antitrypanosomal and Antioxidant Activities of Moringa oleifera Lam Leaf Extracts. Journal of Pharmaceutical, Chemical and Biological Sciences, 3(1), 17-23.

[40] World Health Organisation, WHO. (2004). World Health Report 2004, Statistical annex.

[41] Woo PTK. (1970). The Haematocrit Centrifuge Technique for the Diagnosis of African Trypanosomiasis. Acta Trop, 27, 384-386.

\section{How to cite this article}

Datti Y, Musa I, Ali UL, Mustapha A, Tijjani YA, Koki IB, Ado AS, Musa SM Adamu GA and Umar A. (2020). Evaluation of the in-vivo antitrypanosomal activity of the crude extract of Moringa oleifera (lam) against rats infected with Trypanosoma brucei. GSC Biological and Pharmaceutical Sciences, 11(1), 12-17. 